\title{
FOTODISSZOCIÁCIÓ SZABÁLYOZÁSA THZ PULZUSSAL INDUKÁLT STARK EFFEKTUSSAL
}

\author{
Tóth A. ${ }^{1}$, Csehi A. ${ }^{2}$, Halász G. J. ${ }^{3}$, és Vibók Á. ${ }^{2,1}$ \\ ${ }^{1}$ ELI-ALPS, ELI-HU Non-Profit Ltd,H-6720 Szeged, Dugonics tér 13, Magyarország \\ ${ }^{2}$ Elméleti Fizikai Tanszék, Debreceni Egyetem, H-4010 Debrecen, PO Box 5, Magyarország \\ ${ }^{3}$ Információ Technológiai Tanszék, Debreceni Egyetem, H-4010 Debrecen, PO Box 12, \\ Magyarország
}

DOI: https://doi.org/10.14232/kvantumelektronika.9.34

\section{Bevezetés}

A lézertechnológia elmúlt évtizedekben történt folyamatos fejlődésének köszönhetôen napjainkra femtoszekundumos vagy akár néhány attoszekundumos lézerpulzusok is a kutatók rendelkezésére állnak. Ezek a példátlan időfelbontást biztosító pulzusok elengedhetetlen kellékei a hasonló időskálán zajló fizikai folyamatok vizsgálatának. Ennek köszönhetően, a lézer-anyag kölcsönhatás tanulmányozása az egyik leggyorsabban fejlődő kutatási területté vált, amely számos új jelenség - mint például a magas felharmonikusok keltése vagy fotoionizáció és fragmentáció - felfedezéséhez vezetett.

Az atomok és molekulák belsejében lezajló dinamikai folyamatok megértése mellett egyre nagyobb hangsúlyt kap ezek ellenőrzött irányítása [1,2]. Erre az egyik legnépszerúbb stratégia a dinamikus Stark effektus (DSE) használata. Az alkalmazott lézerfény frekvenciája szerint ez lehet rezonáns vagy nem-rezonáns. Az első esetben, molekulákra alkalmazva, az erős lézersugárzás képes csatolni két elektronállapotot a molekula átmeneti dipólusmomentumán keresztuil. Ennek hatására elfajulások, úgynevezett kónikus kereszteződések jönnek létre, amelyeken keresztül lezajló nemadiabatikus folyamatok erőteljesen befolyásolják a molekula dinamikai, illetve spektroszkópiai tulajdonságait. A másik, nem-rezonáns esetben a lézerfény továbbra is képes jelentős dinamikai hatásokat kifejteni a potenciálisenergia-felületeknek (potential energy surface, PES) permanens dipólusmomentumon keresztül történő formálásával. Ezt a hatást átfogóan tanulmányozták az irodalomban, mivel egy általános eszközként szolgál atomi és molekuláris folyamatok kvantumszabályozására [3, 4]. A vizsgált rendszer tekintetében a dinamikus Stark effektus dipólus vagy Raman közelítésben írható le. A köztük lévő különbség abban nyilvánul meg, hogy míg a dipólus esetben a kölcsönhatás a lézer pillanatnyi elektromos terét követi, addig a Raman esetben a pulzus burkolóját.

A közelmúltban néhány kutatócsoport figyelme a terahertzes pulzusok felé irányult. Fleischer és munkatársai a molekulák egyciklusú THz pulzusok hatására történő irányítottságát vizsgálták [5]. Ugyanez a csoport tanulmányozta a térmentes forgási mozgás lecsengését a terahertzes mező által indukált molekuláris orientáción keresztuil [6]. Kurosaki és munkatársai egy módszert javasoltak hullámcsomagok időbeli szétválasztására. Lineárisan poláros egyciklusú THz pulzusok segítségével sikerült szétválasztaniuk a ${ }^{133} \mathrm{CsI}$ és ${ }^{135} \mathrm{CsI}$ izotopológok keverékét [7]. Došlić egyciklusnál rövidebb $\mathrm{THz}$ impulzusokat használt elektronállapot függő populációtranszfer elérésére az ACAC molekulában [8].

A jelen munka a fent említett két irány ötvözése, azaz a molekulák viselkedését irányító Stark hatást terahertzes pulzusokkal keltjük. A hullámcsomagok dinamikájának részletes vizsgálatával igyekszünk meghatározni a rendszert befolyásoló fő mechanizmusokat és ezek nyomait olyan fizikai 
mennyiségekben mint a fotofragmentumok szögeloszlása és kinetikus energia spektruma. Mindezt a lítium-fluorid (LiF) molekula példáján keresztül tesszük.

\section{Módszer}

A lítium-fluorid molekula az alkáli-halogenidek csoportjába tartozik. Ezek közös jellemzője a legalacsonyabban fekvô két ${ }^{1} \Sigma^{+}$elektronállapotuk közötti elkerült keresztezôdés (avoided crossing, a továbbiakban AC), ami miatt a nemadiabatikus folyamatok tanulmányozásának népszerú kísérleti alanyaivá váltak. Korábbi eredményeinket alapul véve [9], a LiF molekulát, mint egy háromállapotú rendszert modellezzük, ahol az előbb említett $1^{1} \Sigma^{+}$és $2^{1} \Sigma^{+}$állapotok mellett az $1^{1} \Pi$ elektronállapotot is figyelembe vesszük. A továbbiakban $\Sigma_{1}, \Sigma_{2}$ és $\Pi_{1}$ néven hivatkozunk rájuk. A nekik megfelelő potenciálisenergia-görbék az 1.(a) ábrán láthatók, a $\Sigma$ állapotokat az AC-nál összekötő csatolási taggal $\left[\tau(R)=\left\langle\varphi_{\Sigma_{1}} \mid \frac{\partial}{\partial R} \varphi_{\Sigma_{2}}\right\rangle\right]$ együtt. Az ábra további paneljei a molekula (b) állandó $\left[\mu_{i}(R)=-\left\langle\varphi_{i}\left|\sum_{k} r_{k}\right| \varphi_{i}\right\rangle\right]$ és (c) átmeneti $\left[\mu_{i j}(R)=-\left\langle\varphi_{i}\left|\sum_{k} r_{k}\right| \varphi_{j}\right\rangle\right]$ dipólmomentumait (TDM) mutatja be. Fontos jellemzője az átmeneti dipólmomentumoknak, hogy míg a $\Sigma_{1}-\Sigma_{2}$ átmenetért felelős $\vec{\mu}_{\Sigma_{1} \Sigma_{2}}$ párhuzamos a molekulatengellyel, addig a $\Pi_{1}$ állapotot csatolóak merőlegesek erre az irányra.

Előző munkáinkban [9] azt is megmutattuk, hogy a molekuladinamika valósághú leírásához a szimulációkban figyelembe kell vennünk a forgási szabadsági fokot. A terahertzes sugárzás köztudottan erôs forgató hatását figyelembe véve, a jelen esetben ez hatványozottan érvényes. Ennek megfelelően a rendszer időfüggó Hamilton operátora a

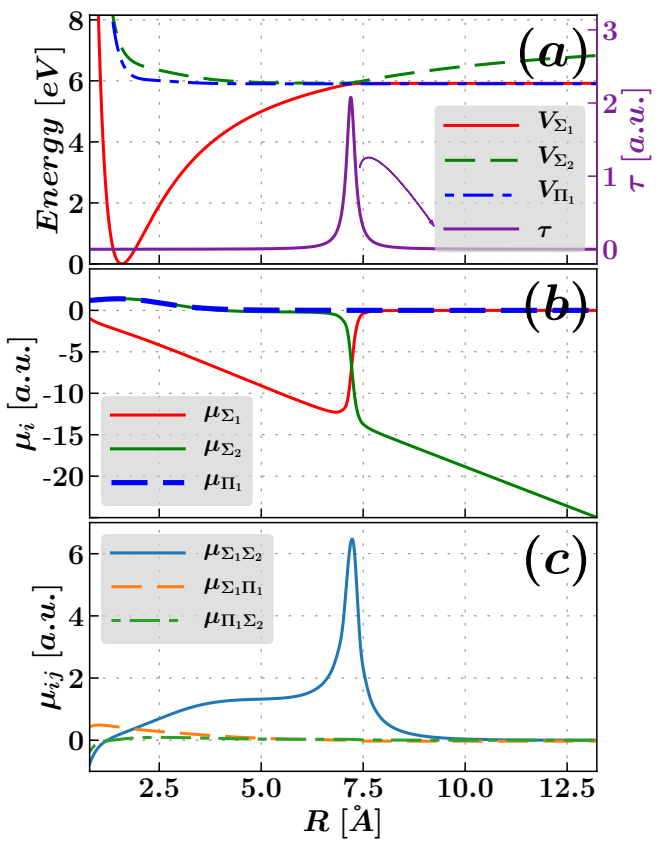

1. ábra. (a) LiF molekula legalacsonyabb három adiabatikus potenciálisenergia görbéje és a $\Sigma$ állapotok közötti nemadiabatikus csatolási tag. (b) A három állapot permanens dipólmomentuma. (c) A különböző állapotok közötti átmeneti dipólmomentum.

$$
\hat{\mathrm{H}}=\left(\begin{array}{ccc}
T & 0 & K \\
0 & T & 0 \\
-K & 0 & T
\end{array}\right)+\left(\begin{array}{ccc}
V_{\Sigma_{1}}-\mu_{\Sigma_{1}} \cos (\theta) E(t) & -\mu_{\Sigma_{1} \Pi_{1}} \sin (\theta) E(t) & -\mu_{\Sigma_{1} \Sigma_{2}} \cos (\theta) E(t) \\
-\mu_{\Sigma_{1} \Pi_{1}} \sin (\theta) E(t) & V_{\Pi_{1}}-\mu_{\Pi_{1}} \cos (\theta) E(t) & -\mu_{\Pi_{1} \Sigma 2} \sin (\theta) E(t) \\
-\mu_{\Sigma_{1} \Sigma_{2}} \cos (\theta) E(t) & -\mu_{\Pi_{1} \Sigma_{2}} \sin (\theta) E(t) & V_{\Sigma_{1}}-\mu_{\Sigma_{2}} \cos (\theta) E(t)
\end{array}\right)
$$

alakban írható, ahol $T$ a forgó-rezgő molekula kinetikusenergia operátora, $K$ pedig az 1.(a) ábrán bemutatott $\tau(R)$ csatolási tagból származtatott nemadiabatikus csatolási operátor [10].

A Hamilton operátor kifejezésében $E(t)$ a lézertér pillanatnyi elektromos terének értékét jelöli. Számításaink során két lineárisan polarizált (azonos irányba mutató) pulzust használtunk. Az első egy 20 fs hosszú (félértékszélesség) pumpa pulzus, melynek fotonenergiája $\hbar \omega_{p}=6.94 \mathrm{eV}$, míg intenzitása $I_{p}=5 \times 10^{12} \mathrm{~W} / \mathrm{cm}^{2}$ volt. Ez gerjesztette a kezdetben alapállapotban lévő molekulát, beindítva ezzel a fotodisszociációs folyamatot. A második, a kontroll pulzus, egy $\hbar \omega_{c}=0.037 \mathrm{eV}$ energiájú és $I_{c}=3.16 \times 10^{13} \mathrm{~W} / \mathrm{cm}^{2}$ intenzitású egyciklusú (félértékszélesség) terahertzes pulzus.

A maghullámfüggvény időfejlődését leíró Schrödinger-egyenletet az MCTDH (multi configuration time-dependent Hartree) módszer segítségével oldottuk meg. Ez egy hatékony eljárás, amely akár 25-30 módust is képes leírni. Esetünkben kétdimenziós számolásokra került sor az $R$ rezgési és $\theta$ forgási (molekulatengely és a lézer polarizációs iránya által bezárt szög) szabadsági fokok által meghatározott konfigurációs térben. A kapott hullámcsomagokból aztán kiszámoltuk az egyes elektronállapotok populációját, illetve a fragmentálódó részecskék szögeloszlását és kinetikusenergia spektrumát. 


\section{Eredmények}

Az irodalomban található munkák túlnyomó része a nem-rezonáns dinamikus Stark effektust (NRDSE) alkalmazza a Raman közelítésben. A kölcsönhatás következtében módosul a potenciálisenergia-felületek alakja, így az AC kereszteződésen áthaladó hullámcsomagok sebessége is, ami a Landau-Zener képlet szerint a fotofragmentumok elektronállapot szerinti arányának módosulásához vezet. A jelen munka alapvetô különbsége, hogy a LiF molekula elektronállapotai dipólus-csatoltak, ami azt jelenti, hogy az elsőrendû DSE érvényes. Ennek következtében a kölcsönhatás a pillanatnyi elektromos teret követi. Emel-

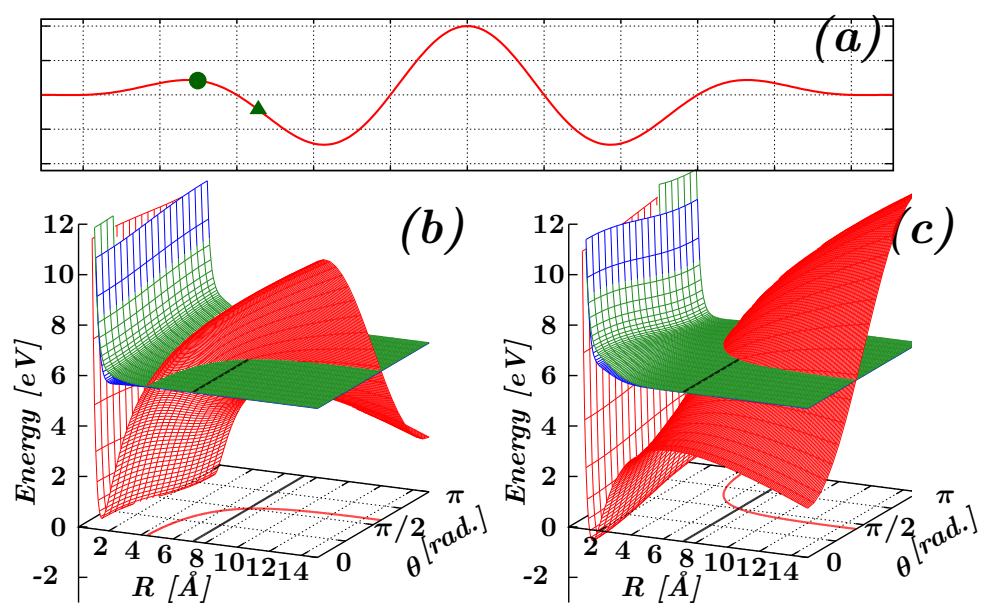

2. ábra. (a) A cikkben használt $\mathrm{THz}$ lézerpulzus alakja. Fénnyel indukált potenciálisenergia-felületek (LIPs) két különböző, az (a) panelen jelölt, időpillanatban: (b) zöld kör, (c) zöld háromszög. lett, a kontroll pulzus intenzitása viszonylag nagy, ami a potenciálisenergia-felületek jelentôs torzulásához vezet. Ezt a 2. ábra szemlélteti, amelyen a (b) és (c) panelek a számolások során használt terahertzes lézer pulzus ((a) panel)
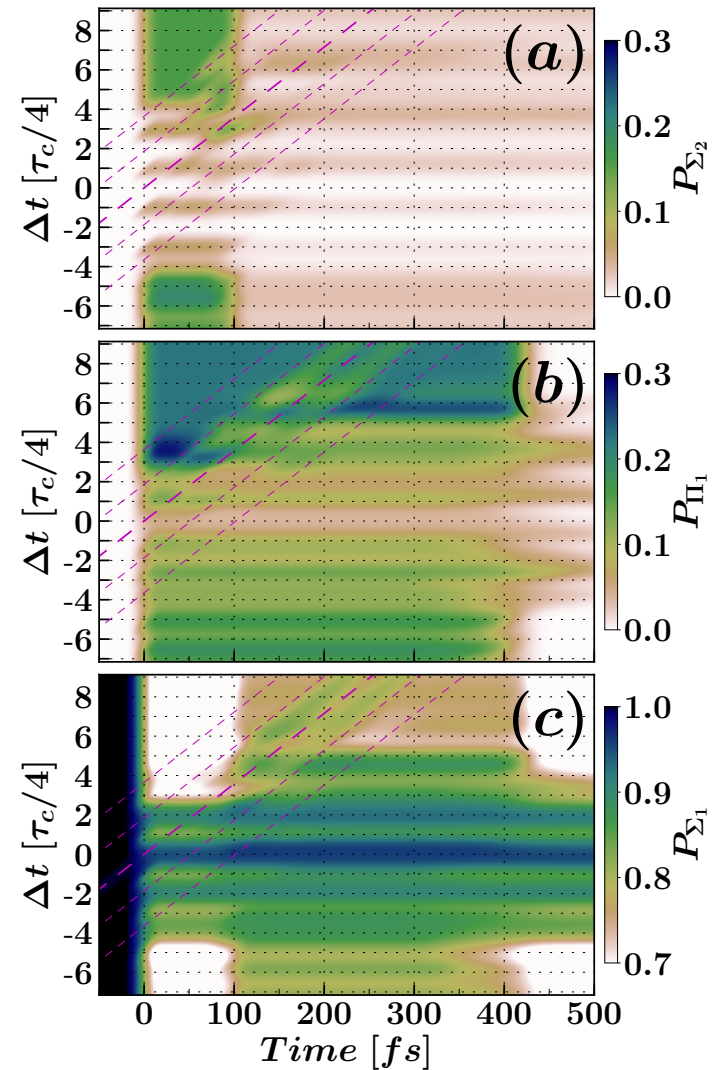

3. ábra. Az elektronállapotok populációjának fejlődése $\Delta t$ függvényében. Ferde lila vonalak jelzik az időpillanatokat, amikor a kontroll pulzus elektromos terének minimuma/maximuma van. két időpillanatához tartozó fénnyel indukált potenciális energia-felületeit (light-induced potentials, LIPs) mutatja be. Ezeket a Hamilton operátor 1. képletében szereplố potenciálisenergia-mátrixnak (második tag) a diagonalizációjával kapjuk.

A dinamikus Stark hatást általában a pumpa és a kontroll pulzus közötti időeltolás függvényében vizsgálják. Mi is ezt a hagyományt követtük, és elsô lépésben a három elektronállapot populációjának időfejlődését vizsgáltuk a kontroll pulzus $\Delta t$ késleltetésének függvényében. Számolásainkat véletlenszerú térbeli orientációjú molekulákra végeztük, amelyek kezdeti állapotát a $\Sigma_{1}$ elektronállapot alap forgási $J=0$ és alap vibrációs $\nu=0$ sajátállapota képezte. A kapott eredményeket a 3. ábra mutatja be, ahol az időeltolás a kontroll pulzus periódusidejének ( $\left.\tau_{c}=111.77 \mathrm{fs}\right)$ egységeiben van kifejezve. Az ábra alapján nyilvánvaló, hogy a kontroll pulzusnak markáns hatása van ezekre a populációkra. A legszembetűnőbb jellemző a pumpa folyamat elnyomása, amikor a két pulzus idôben fedi egymást. A gerjesztett populációk azonban nem csak lecsökkennek, hanem a terahertzes pulzus periódusát követô modulációkat mutatnak az időeltolás függvényében. Érdekes megjegyezni, hogy ezek a modulációk akkor is jelentkeznek, ha a Stark pulzus megelózi a pumpát. A másik fontos jelenség a dinamika megkezdése után történő populációtranszfer a kontroll pulzus szélsőértékeinél, ami hatással van a $\Sigma_{1} / \Pi_{1}$ csatornákon történô disszociáció 
arányára.

A fenti észrevételeket áttekinthetôbb formában mutatja a 4. ábra. Szaggatott vonalak csillagokkal jelölik a gerjesztési-, míg folytonos vonalak körökkel a disszociációs valószínúséget. Zöld és kék szín jelzi a $\Sigma_{2}$ illetve $\Pi_{1}$ elektronállapotokra vonatkozó mennyiségeket, míg a piros színú vonalak ezek összegeit. Azonos színkódú pontozott és szaggatott-pontozott vízszintes vonalak mutatják a rendszer gerjesztési és disszociációs valószínúségét a Stark pulzus hiányában. Látható, hogy megfelelően hosszú időeltolás esetén $\left(\sim 5 \tau_{c} / 4\right)$ a gerjesztett populációk a kontroll-mentes értékeikhez konvergálnak. Kisebb késleltetés esetében, amikor a kontroll megelőzi a pumpa pulzust a $\Pi_{1}$-re gerjesztett populáció alulmúlja, míg a $\Sigma_{2}$ meghaladja a kontrollmentes értékét. A közbeesô tartományban, mi-

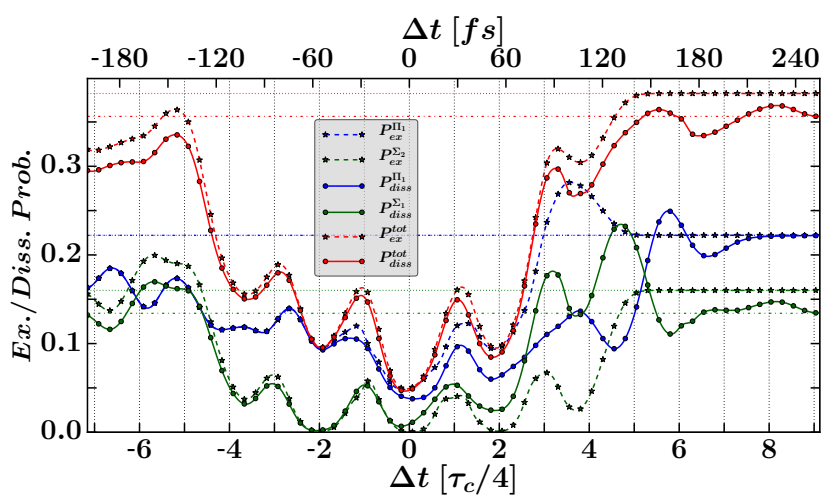

4. ábra. Kék és zöld szaggatott vonalak jelzik a $\Pi_{1}$ és $\Sigma_{2}$ elektronállapotokra gerjesztett populációt, míg a kék és zöld folytonos vonalak a $\Pi_{1}$ és $\Sigma_{1}$ állapotokon történő disszociáció valószínúségét. A piros vonalak a gerjesztett és disszociáló populációk összegét jelölik. kor a két pulzus egyidejüleg van jelen, a gerjesztés lényegesen lecsökken, és csak rövid ideig jöhet létre a kontroll pulzus nulla-pontjai körül.

A rendszer viselkedésének oka, hogy a terahertzes sugárzás bár nem képes átmeneteket előidézni az elektronállapotok között, rotációs és vibrációs gerjesztéseket vált ki. Ennek következtében a $\Sigma_{1}$ állapoton egy forgási hullámcsomag jön létre, ami a gerjesztett populációk modulációját okozza negatív $\Delta t$ értékeknél, mivel a pumpa pulzus már nem az eredeti izotrop eloszlást találja. Továbbá, a hullámcsomag különböző komponenseinek kölcsönhatása egy interferenciamintázat megjelenéséhez vezet, ami a fotofragmentumok szögeloszlásában is megmutatkozik. Ezeket a szögeloszlásokat a 5. ábra bal oszlopa mutatja. Megfigyelhető, hogy abban az esetben ha a kontroll pulzus megelőzi a pumpát, a disszociáció fôként a lézer polarizációs iránya mentén történik, és túlnyomórészt a $\Sigma_{1}$ állapoton. Ez annak köszönhető, hogy a THz pulzus az eredetileg véletlenszerúen orientált molekulákat a saját polarizációs irányába rendezi.

A két pulzus idôbeli átfedése alatt tapasztalt pumpálási hatékonyság csökkenés a fénnyel indukált potenciálisenergia-felületek segítségével érthető meg. Amint azt láttuk, a terahertzes pulzus a rendszer forgási gerjesztését idézi elő. A LIPs képben ez a potenciálisenergia-felületek $\theta$ koordináta menti deformációjában nyilvánul meg: adott magtávolságon a $\mu_{i} \cos (\theta) E(t)$ kölcsönhatási tag által a felületek megemelkednek vagy lesüllyednek a térmentes helyzetükhöz képest, azaz a $\theta=\{0, \pi\}$ irányokba periodikusan potenciálgödrök jönnek létre. Emiatt az izotrop kezdeti eloszlás ezekbe a potenciálgödrökbe koncentrálódik. A másik fontos tényezô, hogy a gerjesztett állapotok állandó dipólusmomentumai ellenkezô elôjelúek a Franck-Condon régióban mint az alapállapoté, így ellenkező irányba mozdulnak el. Ennek következtében amikor az alapállapoti hullámcsomag a lézerrel keltett potenciálgödörben összpontosul, az elektronállapotok közötti energiakülönbség meghaladja a pumpa pulzus energiáját, és a populáció transzfer nem jön létre. Erre az átvitelre csak rövid ideig van lehetőség a kontroll tér nullpontjai körül.

A $\Pi_{1}$ állapot viselkedése különösen érdekes. A pumpa energia a $\Sigma_{1}-\Sigma_{2}$ átmenetre volt hangolva, így a $\Sigma_{1}-\Pi_{1}$ rezonanciafeltétel a $\theta$ koordináta mentén változik a felületek kontroll pulzus által előidézett lengése során. Ez megfigyelhetô a fragmentumok szögeloszlásában is a $\Delta t \in\left[-3 \tau_{c}, 5 \tau_{c}\right]$ intervallumban. $\mathrm{A} \Pi_{1}$ állapothoz tartozó átmeneti dipólmomentumok merôlegesek a molekulatengelyre, így a csatolás a felületek azon részén a legerôsebb, ahol a kontroll tér általi torzítás a leggyengébb. Mivel a $\Pi_{1}$ állapot alacsonyabban fekszik mint a $\Sigma_{2}$, a rezonanciafeltétel a kontroll pulzus előjelváltása elôtt teljesül, amikor az alapállapoti hullámfüggvény még a lézer polarizációs irányába összpontosul. Emiatt a populáció átvitel is itt történik a gyengébb csatolás ellenére is. Ráadásul, a tér előjelváltása 

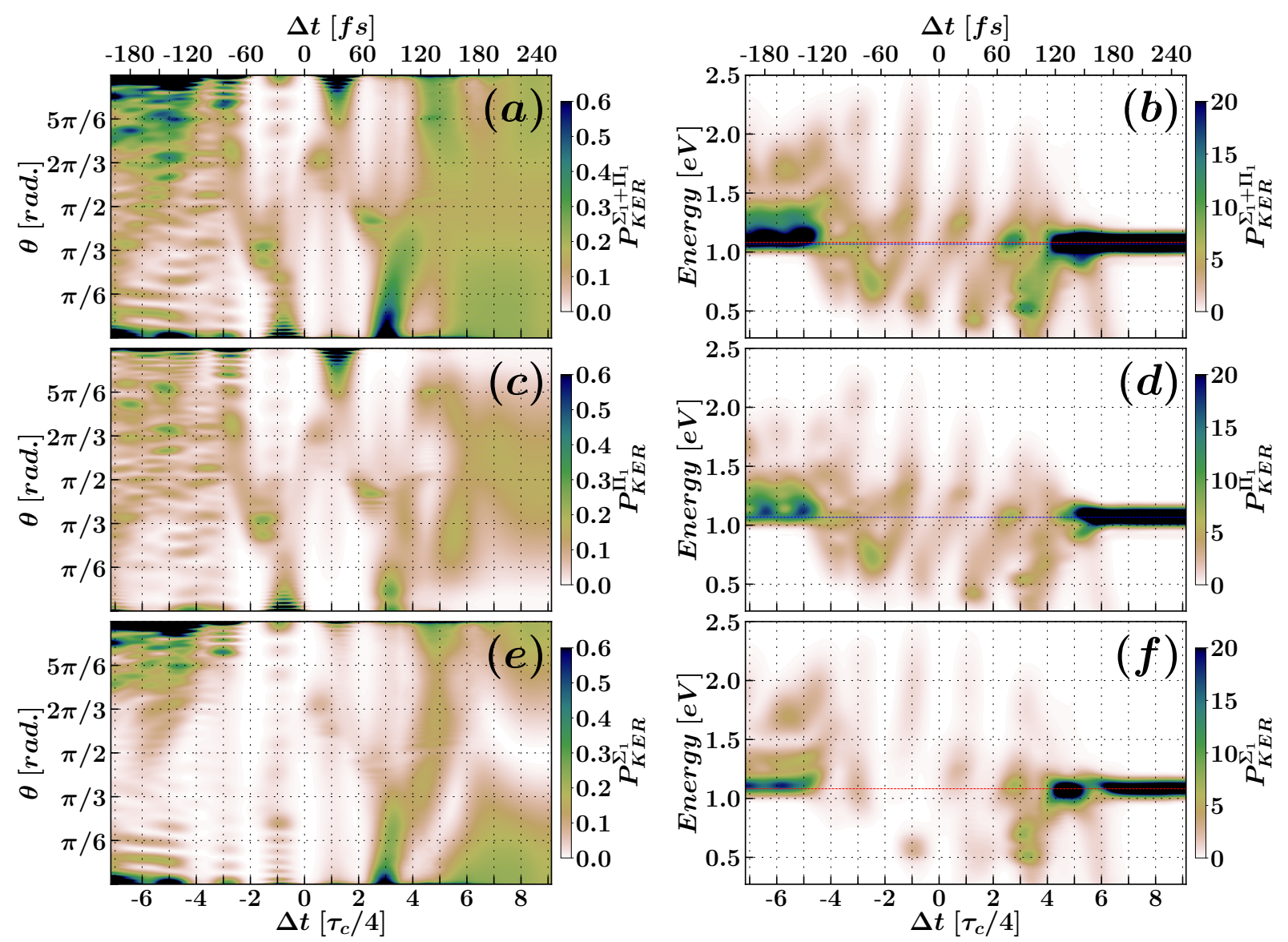

5. ábra. Disszociáló fragmentumok szögeloszlása és kinetikus energia eloszlása: (c), (d) $\Pi_{1}$ állapot; (e), (f) $\Sigma_{1}$ állapot; (a), (b) a két disszociációs csatorna összege.

után a gerjesztett állapotokon alakulnak ki potenciálgödrök, ami a $\Pi_{1}$ állapotra került hullámcsomagot a $\theta=\{0, \pi\}$ irányba forgatja, előidézve ezzel a szögeloszlásban látható interferenciamintázatot. Ha a kontroll pulzust a rendszer gerjesztése után alkalmazzuk, de mielőtt a hullámcsomagok elérnék az AC kereszteződést, a fentebb említett populáció transzfer nyomait látjuk a szögeloszlásokban: a polarizációs irányra merőleges fragmentumok jelennek meg a $\Sigma_{1}$ csatornán, míg a disszociációs valószínúség lecsökken a $\Pi_{1}$ állapoton. Nagyobb idôeltolások esetén a szögeloszlások a kontroll-mentes értékeikhez konvergálnak.

A kontroll pulzus hatását a szögeloszlások mellett a disszociáló fragmentumok kinetikus energiájának spektrumában is megtaláljuk. Ezeket az 5. ábra jobb oszlopa mutatja be. A piros és kék vízszintes vonalak a $\Sigma_{1}$ és $\Pi_{1}$ állapotokhoz tartozó spektrumok kontroll-mentes esetben számolt csúcsértékét jelölik. Negatív időeltolások esetén ezeknél magasabb energiákat is találunk, ami a molekula rotációs-vibrációs gerjesztésére utal. Ha a kontroll pulzus jelen van a rendszer gerjesztése és a hullámcsomagok AC-n való áthaladása között, a spektrumok szétkenődnek. Ennek két oka van.

Először is, az energia-felületeknek a Stark hatás miatti lengése a fragmentumok potenciális energiájának módosulását okozza, ami végül a kinetikusenergia spektrumban nyilvánul meg. Ennek a változásnak a mértéke függ a kontroll pulzus fázisától, és attól, hogy a gerjesztett felület melyik tartományára került populáció.

A másik szintén a PES dinamikus változásának következménye. Korábbi munkák [11] rámutattak, hogy a Stark hatás következtében eltorzult energiafelületek a $\Sigma_{1}$ és $\Sigma_{2}$ állapotok közti nemadiabatikus csatolás helyének idôfüggését is eredményezik. Ezt a 2. ábra is illusztrálja, ahol az $R-\theta$ síkban lévő fekete vonalak a AC kereszteződés helyét jelöli kontroll-mentes esetben, míg a piros görbék a fénnyel indukált felületek kereszteződéseit mutatják adott idôpillanatokban. Háromállapotú leírásunkban a $\Sigma_{1}$ és $\Pi_{1}$ állapotok között is kialakul egy kereszteződés, amit a másikhoz viszonyított közelsége miatt 
az ábrán nem tüntettünk fel. Amikor ezek a kereszteződések kisebb magtávolságok felé mozdulnak, a disszociáló hullámcsomag útjába kerülnek, és populációtranszfer történik. Ez úgy is tekinthetô, mintha a hullámcsomag egy potenciálgáttal találkozna, aminek következtében veszít a kinetikus energiájából. Ennek a folyamatnak a nyoma a 4. ábrán bemutatott elektronállapot populációkban a legszembetûnőbb. Miután a kereszteződések mozgásának iránya megváltozik, ismét populációátvitelre kerül sor. Mivel a gerjesztett állapotok közül a $\Sigma_{2}$ fekszik magasabban, és ennek a $\mu_{\Sigma_{1} \Sigma_{2}}$ átmeneti dipólmomentuma erősebb mint $\mu_{\Sigma_{1} \Pi_{1}}$, így az előzőleg a $\Sigma_{1}$ állapotra került hullámcsomag jelentős része a $\Sigma_{2}$-re jut. Ennélfogva, a kontroll pulzus egyirányúan módosítja a két disszociációs csatorna arányát, a $\Sigma_{1}$-et részesítve előnyben.

\section{4. Összefoglalás}

Ebben a munkában egy terahertzes pulzus lítium-fluorid molekula fotodisszociációjára gyakorolt hatását vizsgáltuk. A bemutatott eredmények alapján a legfontosabb következmény a magasabb elektronállapotok gerjesztési hatékonyságának csökkenése. Ennek oka, hogy a kontroll pulzus hatására módosult potenciálisenergia-felületeket a pumpa pulzus már nem képes rezonánsan csatolni. Ez szakaszos pumpáláshoz vezet a kontroll tér nullpontjai körül. A felületek Stark fluktuációja a molekulák térbeli orientációjához, illetve a felületek közti dinamikusan változó kereszteződésekhez vezet. A disszociáló hullámcsomag ez utóbbiakkal való találkozása populációtranszfert eredményez, ami képes jelentôsen módosítani a $\Sigma_{1} / \Pi_{1}$ fragmentációs csatornák valószínúségi arányát.

\section{Köszönetnyilvánítás}

A kutatást az EFOP-3.6.2-16-2017-00005 azonosítójú, EU társfinanszírozású projekt támogatta. Az ELI-ALPS projekt (GINOP-2.3.6-15.-2015-00001) az Európai Unió támogatásával, az Európai Regionális Fejlesztési Alap társfinanszírozásával valósul meg.

\section{Irodalom}

[1] P. W. Brumer és M. Shapiro, Principles of the Quantum Control of Molecular Processes (John Wiley \& Sons, 2003)

[2] G. A. Worth és G. W. Richings, Annu. Rep. Prog. Chem. Sect. C: Phys. Chem. 109, 113 (2013) https://doi.org/10.1039/C3PC90003G

[3] B. J. Sussman, D. Townsed, M. Y. Ivanov, és A. Stolow, Science 314, 278 (2006) https://doi.org/10.1126/science.1132289

[4] D. Townsed, B. J. Sussman, és A. Stolow, J. Phys. Chem. A 115, 357 (2011) https://doi.org/10.1021/jp109095d

[5] S. Fleischer, Y. Zhou, R. W. Field, és K. A. Nelson, Phys. Rev. Lett. 107, 163603 (2011) https://doi.org/10.1103/PhysRevLett.107.163603

[6] R. Damari, D. Rosenberg, és S. Fleischer, Phys.Rev. Lett. 119, 033002 (2017) https://doi.org/10.1103/PhysRevLett.119.033002

[7] Y. Kurosaki, H. Akagi, és K. Yokoyama, Phys. Rev. A 90043407 (2014) https://doi.org/10.1103/PhysRevA.90.043407 
[8] N. Došlic, J. Phys. Chem. A 110, 12400 (2006) https://doi.org/10.1021/jp064363i

[9] A. Tóth, A. Csehi, G. J. Halász, és Á. Vibók, Phys. Rev. A 99043424 (2019) https://doi.org/10.1103/PhysRevA.99.043424

[10] A. Hofmann és R. de Vivie-Riedle, Chem. Phys. Lett. 346299 (2001) https://doi.org/10.1016/S0009-2614(01)00922-8

[11] S. Scheit, Y. Arasaki, és K. Takatsuka, J. Chem. Phys. 140244115 (2014) https://doi.org/10.1063/1.4884784 